\title{
Presence and identification of Legionella and Aeromonas spp. in the Great Masurian Lakes system in the context of eutrophication
}

\author{
Karolina Grabowska, ${ }^{*}$ Aleksandra Bukowska, ${ }^{1}$ Tomasz Kaliński, ${ }^{1}$ Bartosz Kiersztyn, ${ }^{1}$ Waldemar Siuda, ${ }^{1}$ Ryszard J. Chróst ${ }^{1,2}$ \\ ${ }^{1}$ Department of Microbial Ecology and Environmental Biotechnology, Faculty of Biology, University of Warsaw; ${ }^{2}$ Laboratory of \\ Protection and Reclamations of Natural Waters, Biological and Chemical Research Centre, University of Warsaw, Żwirki i Wigury \\ 101, 02-089 Warszawa, Poland
}

\begin{abstract}
Growing anthropopressure over the last several decades has resulted in rapid progressive eutrophication of the Great Masurian Lakes (GML) system located in northeastern Poland. In our studies, we investigated whether there is a relationship between the occurrence of pathogenic bacteria: Legionella spp. and Aeromonas spp., not explored so far in the waters of GML system, and the trophic status of the studied lakes. The GML system of glacial origin includes lakes connected by natural and artificial channels, and it extends from north to south for approximately 100 kilometers. Water samples were taken during the summer, subsequently spring and autumn seasons from 15 lakes in land-water ecotones. At all sampling sites, basic in situ measurements of physicochemical parameters were recorded. The amounts of chlorophyll $a$, nitrogen, phosphorus, dissolved organic carbon were also measured. The trophic state index (TSI) of the sampling sites was also estimated. The real-time PCR technique enabled the determination of the presence and abundance of Legionella spp. and Aeromonas spp. The results clearly showed that several environmental water quality parameters, associated with eutrophication, and among them: nitrogen, phosphorus, chlorophyll, ammonium concentration, conductivity, turbidity, water transparency, highly affected the presence and abundance of the detected pathogenic bacteria in the studied lakes. Special attention should be paid to the high impact of water eutrophication on the number of pathogenic microorganisms, which result both from human activities in lakes and climate change.
\end{abstract}

\section{INTRODUCTION}

The contamination of water bodies by water-borne pathogens and the human health safety related to the pathogen contamination are some of the major water quality concerns around the world (Pandey, 2014). According to The World Health Organization (WHO), approximately 3.4 million people, mainly children, die from water-related diseases every year (WHO, 2016). Water-borne diseases are a problem not only in developing countries (although they are prevalent) but also in well-developed countries (Arnone and Walling, 2007; Wacnik, 2009). Studies conducted by the U.S.

Corresponding author: karolina.grabowska@biol.uw.edu.pl

Key words: eutrophication; lakes; Aeromonas species; Legionella species.

Edited by: Andrea Di Cesare, CNR-IRSA Verbania, Italy.

Received: 28 June 2019.

Accepted: 24 October 2019.

This work is licensed under a Creative Commons Attribution NonCommercial 4.0 License (CC BY-NC 4.0).

${ }^{\circ}$ Copyright: the Author(s), 2019

Licensee PAGEPress, Italy

J. Limnol., 2020; 79(1): 30-42

DOI: 10.4081/jlimnol.2019.1924
Environmental Protection Agency revealed that pathogens are leading factors of water impairment (Pandey et al., 2014). In turn, all infectious diseases caused by bacterial pathogens are major causes of death throughout the world (Binder et al., 1999), which demonstrates the great danger posed by pathogenic microorganisms. Many infectious diseases are caused by anthropogenic disturbances to aquatic systems, including the overuse of water resources, climate change and animals and human pollution impact (Ahmed et al., 2016; Cavicchioli et al., 2019). To predict the survival and transport of pathogens at the watershed scale, several models were developed (Dorner et al., 2006; Cho et al., 2016). However, many pathogen transport models consider only temperature-induced mortality and growth, and they omit the interplay with other environmental water quality factors, such as biogen (nitrogen, phosphorus, carbon) concentration, organic matter content, and several physical and chemical properties of the aquatic environment. Greater amount of nutrients increases the amount of sediments, which are a reservoir and source of nutrients for pathogenic bacteria (Pandey et al., 2014). The presence of microorganisms is also influenced by hydrometeorological changes such as heavy rainfalls and elevated temperatures which increase with climate change (Jung et al., 2014). Rainfalls cause increased surface runoff, providing allochthonic microflora and enriching the aquatic environment with biogenic substances from the catchment area. That allows the development of both autochthonous and allochthonous microflora. Furthermore, several studies 
have shown consistent and significant association between heavy rainfall events and waterborne disease outbreaks (Jung et al., 2014; Levy et al., 2016).

In natural and pristine water ecosystems, phosphorous or nitrogen contents are the limiting factors for plankton biomass production. However, human activity has changed this significantly and accelerated the supply of nutrients; as a consequence, the rates and scales of eutrophication have also increased (Correll, 1999).

Great Masurian Lakes (GML) system consisting of the two hydrologically different parts separated by the line of the watershed placed between Kisajno lake and Niegocin lake (Fig. 1). Both parts of GML system differ distinctly in respect to their morphometry, the trophic status and the level of human impact (Siuda and Kiersztyn, 2014). Present trophic status of the GMLS was shaped by four basic factors: i) geographical location - its division into two separate parts carrying waters into two watersheds and evolving in a diverse way; ii) relatively low anthropogenic impact on catchment areas of northern lakes and strong anthropopressure exerted simultaneously on the catchment areas of southern lakes; iii) political economic and social changes in Poland in the years 1980-1990, which increased a tourism in the region; and iv) climate changes occurring in the last few decades, resulting in an increase in mean daily temperatures in winter, shorter ice cover, and also shortening of autumn and spring homothermic periods (Siuda et al., 2020). Because the microbial contamination of water is often caused by discharge of polluted water from sewage treatment plants as well as from noncollective sewage systems, it is important to monitor microbiological hazards of natural waters. Microbiological and sanitary monitoring of water commonly rely up on simple and rapid indicators, such as fecal bacteria (Escherichia coli or Enterococci) (Jung et al., 2014). So far, the presence of Legionella and Aeromonas spp. in the water reservoirs of the system of the Great Masurian Lakes has not been monitored.

A significant number of studies on microbial pathogen contamination of aquatic systems have been conducted at a laboratory-scale; however, to understand the transition and survival of pathogens in natural water environments, field-scale studies are needed (Pandey et al., 2014). One of the studied pathogens of our interest was Legionella genus, which covers 61 species, and among them, 22 species are responsible for human disease. Legionella pneumophila is responsible for the largest number of legionellosis (Lizana et al. 2017). Pathogenic strains of Legionella spp. are etiological factors of Legionnaires' disease - severe, life-threatening pneumonia - and a lesssevere disease called Pontiac Fever. Contagion occurs by inhalation of Legionella-contaminated water aerosols. Legionella spp. upon transmission to human infect and replicate within alveolar macrophages (Pasqualina et al.,
2017). The capacity to replicate in human macrophages is related with the innate ability of Legionella to replicate within various free-living protozoa. This ability is one of the strategies to survive in unfavorable conditions (Amaro et al., 2015). The host cells enable bacterial replication, and viable released bacteria are more virulent than Legionella spp. that bypassed intracellular multiplication (Richards et al., 2014; Correll, 1999). Legionella spp. are also able to be transformed into a viable but nonculturable forms. All these strategies allow Legionella to resist to biocide compounds and chlorination (Borella et al., 2005). Moreover, these bacteria are remarkably fastidious in axenic cultures which makes it difficult to detect using culture methods. Therefore, real-time PCR is an appropriate method for detecting lower levels of contamination, as well as nonculturable Legionella (Devos et al., 2005; Edagawa et al., 2015). Legionella are bacteria strictly associated with man-made water systems such as cooling towers, swimming pools, air conditioner systems, and plumbing systems. However, these microorganisms are numerous also in natural water reservoirs (Barna et al., 2015). Many studies have shown, that these bacteria multiply at temperature ranging from 20 to $45^{\circ} \mathrm{C}$ (Dimitriadi and Velonakis, 2014). However, Legionella spp. may adapt to aqueous environments even at low temperatures and are able to survive over a wide range of temperatures: from 0 to $63^{\circ} \mathrm{C}$ (Nguyen and $\left.\mathrm{Yu}, 1991\right)$.

Aeromonas was the second genus of bacteria that we focused on in our studies. Today these bacteria are described as emerging pathogens (Batra et al., 2016). Aeromonas are strictly associated with the aquatic environment and were firstly described as pathogens of fishes and other cold-blooded animals. Currently these bacteria are also recognized as a human pathogen. The interest in this genus has increased over previous decades. This is due to widespread occurrence, the increasing antibiotic resistance and ability to survive under unfavorable environmental conditions (Janda and Abbot, 2010). Aeromonas spp. with Aeromonas hydrophila at the forefront, are associated with gastrointestinal, skin, soft tissue, respiratory and urinary tract infections in both immunocompetent and immunocompromised persons (Martino et al., 2014). Because classic culture and biochemical methods for identifying Aeromonas spp. are multi-stage and difficult to interpret, there is need to use molecular methods for reliable identification of Aeromonas spp. (Beaz-Hidalgo et al., 2010; Králová et al., 2016).

The goal of our research was to detect and quantify of Legionella spp. and Aeromonas spp. with particular emphasis on Legionella pneumophila and Aeromonas hydrophila species in lake water with different trophic status belonging to the GML system. We evaluated whether the eutrophication processes in the studied lakes influenced the frequency of occurrence of the studied 
pathogenic strains of bacteria. The research is important in view of complementing the current state of knowledge concerning the relationship between environmental water quality properties and the presence frequency of Aeromonas and Legionella species. Therefore, in our report, we present the results of studies on the relationship between environmental conditions and the presence and abundance of pathogenic bacteria strictly associated with the limnological quality of the water environment Legionella spp. and Aeromonas spp.

\section{METHODS}

\section{Research area}

Our research area comprises lakes connected by natural or artificial channels that constitute the Great Masurian Lakes (GML) system located in northeastern Poland, which extends for approximately $100 \mathrm{~km}$ from south to north. The GML system is located in two river basins. The watershed location is not strictly determined, but it varies between Kisajno Lake and Jagodne Lake. This contractual boundary divides the system into northern (lakes: Przystań, Mamry, Dargin, Kisajno) and southern parts (lakes: Niegocin, Boczne, Jagodne, Szymoneckie, Szymon, Tałtowisko, Tałty, Ryńskie, Mikołajskie, Bełdany, Śniardwy) (Fig. 1). The water reservoirs that constitute this exceptional waterway represent moraine and channel types of postglacial lakes. The part of Poland that comprises the GML system is called the Great Masurian Lake District (GMLD). This part of Poland is a unique area formed by ice sheets of the Pomeranian Phase of the Vistulian Glaciation in the late Pleistocene (Wacnik, 2009). The basic morphological parameters of the studied lakes are presented in Tab. 1. The GML District is characterized by the highest surface water content in Poland. The entire catchment area of the GML system encompasses approximately $3645 \mathrm{~km}^{2}$, of which, the northern lakes cover $615 \mathrm{~km}^{2}$ and the southern lakes cover $3030 \mathrm{~km}^{2}$. This size difference is one reason for the greater exposure of southern lakes to eutrophication processes. The system is located in the same geographical area under similar geological conditions. The area surrounding the lakes is mainly represented by agriculture fields and forests (Chróst and Siuda 2006). Water from the northern lakes is drained by the Węgorapa River to the Pregoła River basin, and water from the southern lakes is drained by the Pisa and Narew Rivers towards the Wisła River basin.

The GMLD is of great importance for tourism and the economy and is intensively used for recreational purpose especially during the summer season (Siuda et al., 2019). The number of tourists in the Masurian region reaches about one million persons per year, with the highest peak from June to August (Kauppinen, 2013).

The sampling procedure was conducted by considering places within easy reach of humans, such as watering locations, ports or sites for water sport practice. The sampling sites were selected by the largest probability of both introduction of allochthonous microflora and human contact with contaminated water, and consequently, the greatest possibility of infection.

Tab. 1. Basic morphological data of the studied lakes, coordinates of sampling locations and mean trophic state index determined during particular research seasons.

\begin{tabular}{lccccccc} 
Lake & $\begin{array}{c}\text { Area } \\
(\mathbf{h a})\end{array}$ & $\begin{array}{c}\text { Max depth } \\
(\mathbf{m})\end{array}$ & $\begin{array}{c}\text { Mean depth } \\
(\mathbf{m})\end{array}$ & $\begin{array}{c}\text { Coordinates of } \\
\text { sampling location }\end{array}$ & $\begin{array}{c}\text { Mean TSI } \\
\text { summer }\end{array}$ & $\begin{array}{c}\text { Mean TSI } \\
\text { spring }\end{array}$ & $\begin{array}{c}\text { Mean TSI } \\
\text { autumn }\end{array}$ \\
Przystań & 115 & 22.8 & 13.4 & $54.207241,21.657892$ & $42.18 \pm 2.18$ & $43.17 \pm 2.25$ & $41.12 \pm 2.96$ \\
\hline Mamry & 2504 & 43.8 & 10 & $54.157234,21.723144$ & $40.20 \pm 8.98$ & $44.22 \pm 2.55$ & $39.40 \pm 3.85$ \\
\hline Dargin & 3030 & 37.6 & 11 & $54.145939,21.731939$ & $42.77 \pm 0.96$ & $41.87 \pm 4.84$ & $51.69 \pm 15.27$ \\
\hline Kisajno & 1896 & 25 & 8.4 & $54.042000,21.738594$ & $52.59 \pm 2.99$ & $43.8 \pm 1.50$ & $49.98 \pm 6.45$ \\
\hline Niegocin & 2600 & 39.7 & 9.9 & $54.009215,21.738598$ & $48.47 \pm 2.76$ & $48.25 \pm 3.54$ & $54.27 \pm 8.93$ \\
\hline Boczne & 183 & 25 & 8.4 & $53.967407,21.758265$ & $50.21 \pm 4.21$ & $50.32 \pm 4.35$ & $53.20 \pm 10.53$ \\
\hline Jagodne & 420 & 37.4 & 8.7 & $53.945283,21.721688$ & $58.53 \pm 2.98$ & $57.95 \pm 2.95$ & $57.27 \pm 4.69$ \\
\hline Szymoneckie & 523 & 28.5 & 8.7 & $53.918687,21.697991$ & $59.27 \pm 2.28$ & $55.71 \pm 3.27$ & $56.07 \pm 5.07$ \\
\hline Szymon & 154 & 2.9 & 1.1 & $53.891046,21.633682$ & $57.58 \pm 1.34$ & $58.48 \pm 1.27$ & $58.08 \pm 1.67$ \\
\hline Tałtowisko & 327 & 39.5 & 14 & $53.880376,21.560412$ & $56.42 \pm 3.00$ & $56.97 \pm 4.14$ & $52.73 \pm 5.38$ \\
\hline Tałty & 1160 & 50.8 & 14 & $53.813409,21.567998$ & $59.33 \pm 3.83$ & $55.33 \pm 2.72$ & $53.10 \pm 5.99$ \\
\hline Ryńskie & 671 & 20.2 & 13.5 & $53.935961,21.544402$ & $59.91 \pm 1.21$ & $58.83 \pm 4.92$ & $54.50 \pm 4.91$ \\
\hline Mikołajskie & 498 & 25.9 & 11.2 & $53.801142,21.570925$ & $59.14 \pm 2.04$ & $55.52 \pm 2.45$ & $53.94 \pm 5.68$ \\
\hline Bełdany & 941 & 46 & 10 & $53.686344,21.578000$ & $60.54 \pm 1.23$ & $58.76 \pm 2.09$ & $56.39 \pm 3.51$ \\
\hline Śniardwy & 11340 & 23.4 & 5.8 & $53.766621,21.842127$ & $42.07 \pm 3.82$ & $42.17 \pm 1.81$ & $50.53 \pm 4.67$ \\
\hline
\end{tabular}


Sampling and experimental procedure

Water samples were taken from the water column of 15 lakes in July 2016, and subsequently from the same sampling sites in May 2017 and in September 2017. Sampling sites were located within land-water ecotones (from 10 to $50 \mathrm{~m}$ distance from the lake shorelines). The sampling sites have been chosen in lake areas exposed to high human recreational activities (swimming areas, yachting ports, etc.). The samples were taken using sterile sampling bathymeter, that was used to take water samples
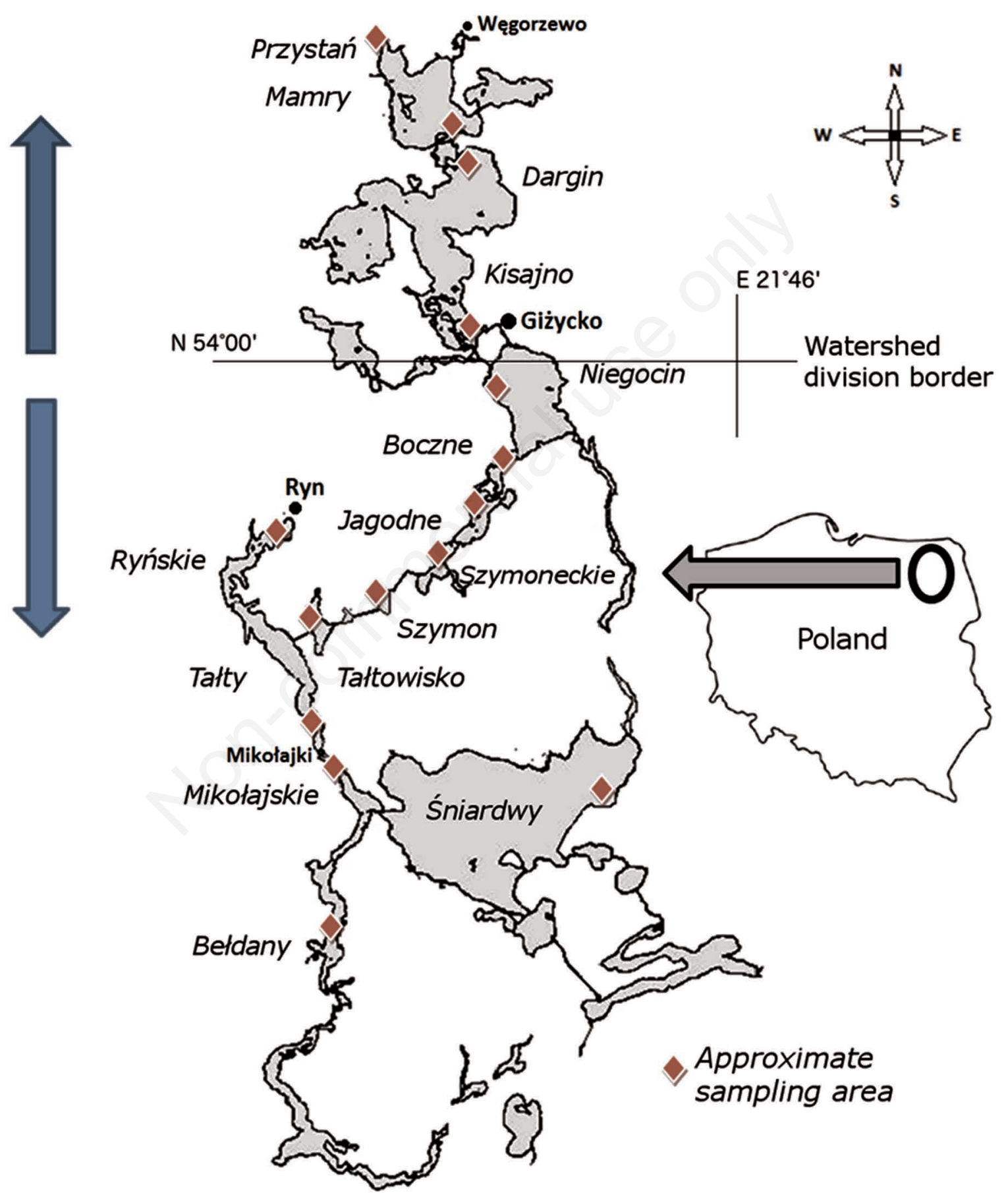

Fig. 1. Locations of sampling sites within the Great Masurian Lakes system. The blue arrows indicate the water flow direction. From the watershed division border to the north the northern lakes are located, from the watershed division border to the south there are southern lakes. 
at a desired depth without the risk of mixing with water from other depths. We took the samples from randomly chosen points within a radius of $30 \mathrm{~m}$ from each of the main sampling sites. The sampling sites are shown in Fig. 1. From every sampling point equal volume of water was sampled from three depths: 1, 2 and 3 meters. All subsamples (about $1.67 \mathrm{~L}$ of every subsample) were mixed $\mathrm{v} / \mathrm{v}$ to a volume of 5 liters and transported as soon as possible under cool temperature conditions to the laboratory where they were subjected to further analysis within 3-6 hours. Using a multiparametric probe YSI6600 (Yellow Spring, USA), the temperature, conductivity, oxygen concentration, $\mathrm{pH}$ and turbidity in the water column (from the water surface to bottom sediments) were measured in situ. The transparency of the water was also measured using a Secchi disk (SD) visibility survey.

Chlorophyll $a(\mathrm{Chl}$ a) content in all water samples was determined according to Arrar and Collins (1997). For this purpose, extraction of $10 \mathrm{~mL}$ water sample with $10 \mathrm{~mL}$ of $98 \%$ acetone and fluorescence measurements at $750 \mathrm{~nm}$, with use of a TD-700 fluorometer were carried out. Dissolved organic carbon (DOC) concentrations in water samples, prefiltered through $0.2 \mu \mathrm{m}$ pore-size polyethersulfone membrane filters (Merck Millipore, USA), were determined using a Shimadzu TOC 5050 carbon analyzer with a detection limit and accuracy of $\pm 50 \mu \mathrm{g} \mathrm{C} \mathrm{L} \mathrm{L}^{-1}$ (Chróst and Siuda, 2006). Phosphorus concentrations, fractions of total phosphorus (TP) and orthophosphates $\left(\mathrm{P}^{-} \mathrm{PO}_{4}\right)$ were determined spectrophotometrically according to Koroleff (1983a) using Shimadzu UV-VIS 1201 spectrophotometer. Total nitrogen (TN) was determined using commercially certified Merck-Millipore cell tests [Spectroquant Nitrogen (Total) Cell Test, 114537] according to the manufacturer's instructions using Merck Spectroquant Pharo 300 spectrophotometer. The ammonium concentrations in the water samples were assayed fluorometrically in a Shimadzu RF 1500 spectrofluorometer, according to Holmes et al. (1999).

\section{Trophic state index}

The trophic state index (TSI) at each sampling site was calculated based on chlorophyll $a$ (Chl $a$ ), total phosphorus concentration (TP) and Secchi disc visibility (SD) according to Carlson (1977). To calculate the TSI, the following equations were used, respectively:

$$
\begin{gathered}
\text { TSI }(\text { Chl a })=9.81 \ln \left(\text { Chl } a \text { in } \mu \mathrm{g} \mathrm{L}^{-1}\right)+30.6 \\
\text { TSI }(\mathrm{TP})=14.42 \ln \left(\mathrm{TP} \text { in } \mu \mathrm{g} \mathrm{L}^{-1}\right)+4.15 \\
\text { TSI }(\mathrm{SD})=60-14.41 \ln (\mathrm{SD} \text { in } \mathrm{m}) .
\end{gathered}
$$

Subsequently, the TSI values calculated separately on the basis of the above, mentioned indicators were averaged, and the mean values of the trophic state of the sampling sites were determined. TSI values between 30 and 40 indicated oligotrophy, values between 40 and 50 indicated mesotrophy, values from 50 to 70 indicated eutrophy, and TSI values above 70 indicated hypereutrophy.

\section{DNA extraction and amplification}

A total of $150 \mathrm{~mL}$ of water from each sample was filtered through polycarbonate membranes with pore sizes of $0.2 \mu \mathrm{m}$ (Nuclepore, Whatman, UK). The filters were placed in sterile $1.5 \mathrm{~mL}$ Eppendorf-type tubes and immediately frozen at $-30^{\circ} \mathrm{C}$ until further DNA extraction. DNA extraction was done using the GeneMATRIX Soil DNA Purification Kit (EURx, Poland) according to the instruction manual supplied by the manufacturer with the modification that concerned the preparation of filters for DNA isolation. The filters were fragmented using sterile laboratory scissors in a bead beating tube containing beads and lysis solution. The aim was to lyse the microorganisms in the filters by a combination of heat, detergent and mechanical force against the beads. Specialized solution was added to precipitate humic substances that strongly inhibit downstream applications. Optimized buffer and ethanol provided selective conditions for DNA binding to the DNA binding spin-columns. Contaminants remaining on the resin are efficiently removed in two washing steps. High-quality DNA was then eluted in low salt buffer. Isolated total DNA was checked for quality and quantity by agarose electrophoresis and a Synergy H1 microplate reader (Gen5 software, BioTek, USA), respectively, and the samples were subsequently stored at $-20^{\circ} \mathrm{C}$ prior to further analysis.

To determine the presence and number of microorganisms of the genus Legionella and the species Legionella pneumophila, the commercial and specific mericon Quant Legionella spp. Kit and mericon Quant $L$. pneumophila Kit (Qiagen, Germany) were applied. These kits are a ready-to-use systems for the detection of specific DNA fragments from Legionella spp. and L. pneumophila in water, food, animal feed and pharmaceutical products using real-time PCR. Using the above mentioned kits, realtime PCR detection and quantification were carried out according to the instructions provided by the manufacturer. The reaction mix per each sample contained $5 \mu \mathrm{L}$ of mericon Assay inclusive Multiplex PCR Master Mix, HotStarTaq Plus DNA Polymerase and specific primers and probes. In case of samples which formed standard curves, the $5 \mu \mathrm{L}$ of respective standard dilutions (from $1.25 \times 10^{1}$ to $1.25 \times 10^{4}$ cells per reaction) of prepared from purified Legionella spp. and L. pneumophila standard DNA were added. Additionally, Quantification control as positive control was applied with $5 \mu \mathrm{L}$ of Quantification control with Legionella spp. and L. pneumophila DNA respectively. Moreover a negative control was applied. An 
appropriate amount of DNA, according to manufacturer's instruction (50ng), in case of tested samples were added to the final reaction volume of $10 \mu \mathrm{L}$. The reaction runs for the quantification of Legionella spp. and $L$. pneumophila cells were as follows: polymerase activation for $5 \mathrm{~min}$ at $95^{\circ} \mathrm{C}$ and 40 cycles comprising denaturation for $15 \mathrm{sec}$ at $95^{\circ} \mathrm{C}$ and annealing and plate read for $23 \mathrm{sec}$ at $60^{\circ} \mathrm{C}$ and final extension for $10 \mathrm{sec}$ at $72^{\circ} \mathrm{C}$. The quantitative detection of Aeromonas spp. was based on the detection of the gene fragment encoding the conserved gyrase B subunit $(\operatorname{gyr} B)$ using primers sequences according to Khan et al. (2009) (forward primer: 5'CTGAACCAGAACAAGACCCCG-3', reverse primer: 5'-ATGTTGTTGGTGAAGCAGTA-3'). The size of amplified fragment was $130 \mathrm{bp}$. Regarding the detection and quantification of $A$. hydrophila in the studied lake water samples, amplification were conducted using the specific primers for gene encoding the Aeromonas hydrophila adhesin (ahal), according to Sebastião et al. (2018): forward primer 5'GAGAAGGTGACCACCAAGAACA-3' and reverse primer 5'-GAGATGTCAGCCTTGTAGAGCT-3'. The length of ahaI fragment was $200 \mathrm{bp}$. In the case of Aeromonas spp. as well as A. hydrophila real-time PCR detection and determination were applied using the $\mathrm{ITaq}^{\mathrm{TM}}$ Universal SYBR ${ }^{\circledR}$ Green Supermix reaction mixture (BioRad, USA). The reaction mixture per sample contained 5 $\mu \mathrm{L}$ of $1 \mathrm{x}$ concentrated iTaq ${ }^{\mathrm{TM}}$ Universal SYBR ${ }^{\circledR}$ Green Supermix, $0.5 \mu \mathrm{M}$ of each primer, around $50 \mathrm{ng}$ of DNA template and nuclease-free water to the final volume of 10 $\mu \mathrm{L}$. All amplification reactions carried out in this study, both for Legionella and Aeromonas, were done in triplicates. A negative control was also applied. In Aeromonas spp. quantification analysis the standard curve was prepared using quantified genetic material isolated from sequenced total DNA of Aeromonas spp. (accession in Sequence Read Archive: PRJNA523334). A. hydrophila quantification was conducted with reference to standard curve prepared from genomic DNA of $A$. hydrophila ATCC 7966 (Minerva Biolabs, Germany). The numbers of Aeromonas and Aeromonas hydrophila were calculated based on the measured DNA concentration and the length of the genome sequence. Then a tenfold series of dilutions (ranging from $10^{6}-10^{0}$ cells) were prepared. This was used to determine both the limit of detection of each assay and to calculate cells number. The minimal reaction efficiencies were of $90-100 \%$ and $0.997<\mathrm{R} 2<0.999$. All amplification reactions were performed using a CFX96 Touch $^{\text {TM }}$ Real-Time PCR detection system (Bio-Rad, USA). The reaction run for the quantification of Aeromonas spp. and A. hydrophila was as follows: polymerase activation for $5 \mathrm{~min}$ at $95^{\circ} \mathrm{C}$ and 40 cycles comprising denaturation for $5 \mathrm{sec}$ at $95^{\circ} \mathrm{C}$ and annealing, extension and plate read for $30 \mathrm{sec}$ at $60^{\circ} \mathrm{C}$. Finally, melt curve analysis was conducted over a temperature gradient from 65 to $95^{\circ} \mathrm{C}$ at $0.5^{\circ} \mathrm{C}$ increments at 5 sec per step. The real-time PCR results were analyzed automatically after entering the standard curve concentrations in the Bio-Rad CFX Maestro 1.1 software. Then the results were calculated into cells per milliliter and liter.

\section{Statistical analysis}

The analyses consisted of series of statistical test. Nonparametric Kruskal-Wallis test was used to check if the lakes were statistically different in terms of amounts of bacteria. To group the lakes according to the Legionella and Aeromonas occurrence profile and physicochemical parameters, two Bray-Curtis based non-metric multidimensional scaling (NMDS) analyzes were conducted. In addition, the ANOSIM test was used to check the differences between seasons. The KruskalWallis, NMDS and ANOSIM tests were done in Past ver. 3.20 software. To elucidate the relationships between Aeromonas and Legionella spp. and their environment, Canonical correspondence analysis (CCA) together with PERMANOVA test were conducted with using $\mathrm{R}$ ver. 3.5.3 and RStudio ver. 1.1.463 software.

\section{RESULTS}

The physicochemical parameters of the lake water measured were averaged across all sampled depths and locations within sampling area are presented in Tab. S1. Based on physicochemical parameter values, Bray-Curtis based non-metric multidimensional scaling (NMDS) was performed (Fig. 2). The analysis allowed the samples to be grouped in terms of their physicochemical properties. First of all, there was a general trend towards grouping according to sampling season (ANOSIM $\mathrm{R}=0.4$, $\mathrm{P}=0.0001$ ). However, the exceptions constituted the samples from spring season: northern lakes: Przystań, Mamry, Dargin, Kisajno, and southern lakes: Bełdany and Śniardwy. The samples from northern lakes, sampled during spring season (Przystań, Mamry, Dargin, Kisajno), showed similarity also with northern lakes tested during summer season (Przystań and Dargin). In turn, the summer and spring samples from southern part of The Great Masurian Lakes (GML) system grouped according to geographic origin. The above indicated therefore the grouping of samples relative to the geographical location. In the case of samples taken in autumn, it was also possible to divide into samples groups from the northern part of the GML complex, as well as the southern part. A special case of a water reservoir was Lake Śniardwy - one of the southernmost of the studied area. Despite geographical location, it grouped closer to northern reservoirs - with a lower trophic status. This was 
confirmed in all sampling seasons during the study period.

The trophic state index (TSI) values of the sampling sites within the GML system were defined using three variables: Secchi disc visibility, chlorophyll $a$ concentration, and total phosphorus content, using Carlson's equations (Carlson 1977). Based on the nomenclature for temperate zones, the TSI values in the studied lakes ranged from oligotrophy/mesotrophy, with the lowest TSI value in the case of Mamry Lake during autumn season (TSI 39.4), to eutrophic conditions in the case of Bełdany Lake during summer season (TSI 60.5). In most cases, the trophic status of the particular lakes did not change significantly over the seasons and oscillated more or less within similar range of eutrophication status. However, there were exceptions in the cases of 4 lakes. Dargin lake mean TSI values changed from mesoeutrophic $(\mathrm{TSI}=41.9-42.8)$ to eutrophic $(\mathrm{TSI}=51.7)$ in autumn season. In Kisjano Lake TSI changed from eutrophic (TSI=52.6) to meso-eutrophic $(\mathrm{TSI}=43.8)$ from summer 2016 to spring 2017 (TSI=almost 50), but afterwards from spring 2017 to autumn 2017 the TSI values increased from 41.87 to 49.98 and almost reconverted. The TSI of Niegocin Lake increased from mesoeutrophic (TSI=48.2-48.5) state to eutrophic one (TSI=54.3). In turn, the TSI of Śniardwy Lake increased significantly from meso-eutrophic state $(\mathrm{TSI}=42.1)$ to eutrophic $(\mathrm{TSI}=50.5)$ in autumn. Detailed information concerning the TSI values of the studied water reservoirs in individual research seasons are presented in Tab. 1.

Real-time PCR analysis was used to quantify the presence of Legionella spp., Aeromonas spp. and Aeromonas hydrophila in the studied lake water samples the results are presented in the Figs. 3 to 5. Legionella pneumophila was not detected in none of the studied lake. The Kruskal-Wallis test showed that the differences in the abundances of the Legionella spp. and Aeromonas spp. between individual lakes were statistically significant $(\mathrm{P} \leq 0.0001)$. Based on the number of analyzed bacteria in all studied samples, Bray-Curtis based non-metric multidimensional scaling (NMDS) was conducted (Fig. 6). The grouping of samples was observed in relation to the research season (ANOSIM $\mathrm{R}=0.41, \mathrm{P}=0.0001$ ) and in terms of geographical location (ANOSIM R $=0.2, \mathrm{P}=0.01$ ).

To evaluate the relationship between the water properties of the lakes at the sampling sites and the presence of Legionella spp. and Aeromonas spp., a Canonical correspondence analysis (CCA) was applied (Fig.7). The CCA1 explains $72 \%$ of variability, while CCA2 explains $2 \%$. Additionally, the PERMANOVA analysis was performed to check whether the model and predictors are statistically significant. The analysis showed that the amount of Legionella spp. is significantly positively influenced by chlorophyll $a$ concentration, total phosphorus and nitrogen amount. Moreover, the dissolved

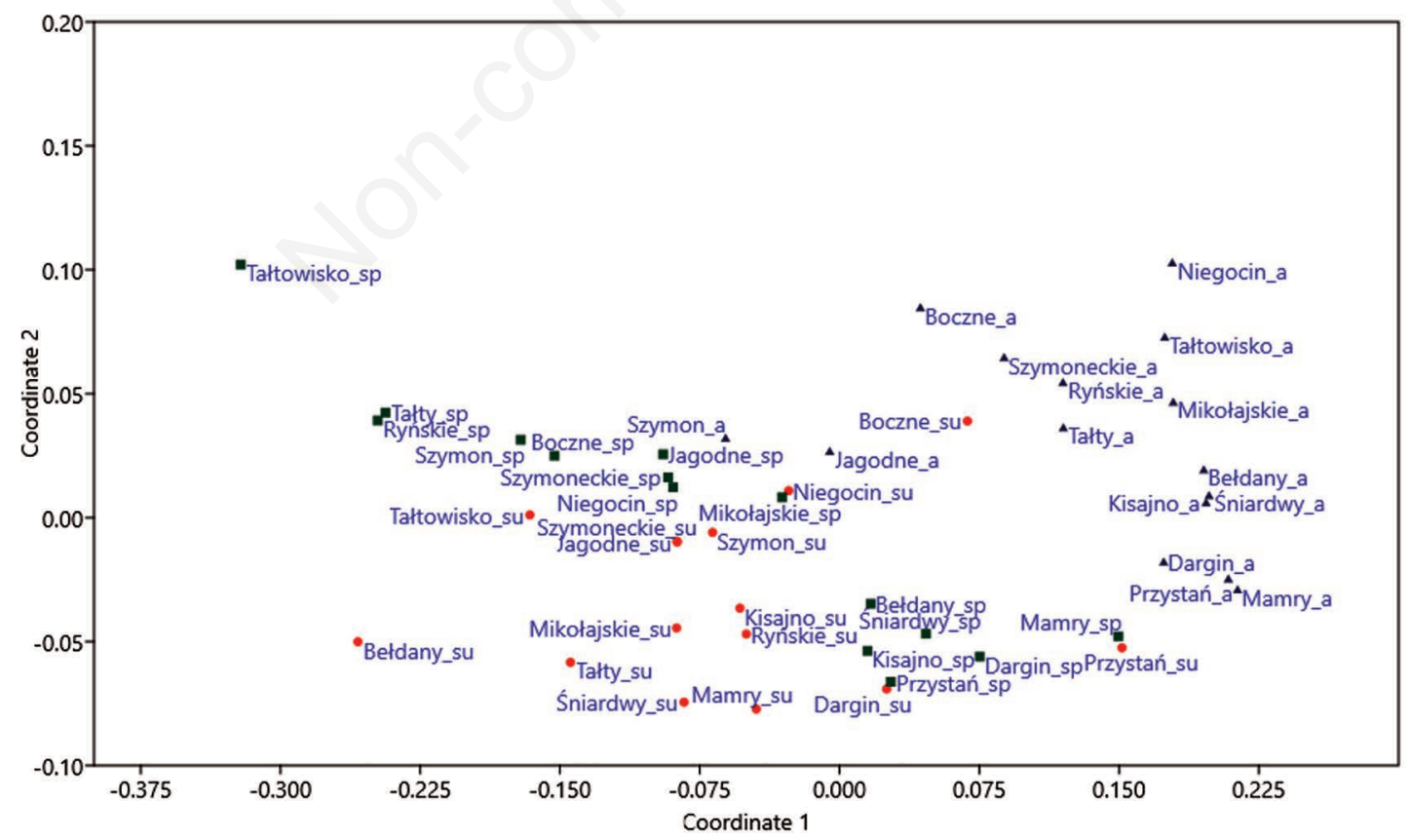

Fig. 2. The Bray-Curtis based non-metric multidimensional scaling (NMDS) of physicochemical water parameters. Stress value $=0.061$. Suffixes added to sampling locations (lake's names) and marks indicate the studied seasons:_su and red dots, summer; _sp and green squares, spring; _a and dark blue triangles, autumn. 
organic carbon concentration and conductivity had a positive moderate influence on Legionella spp. numbers in water of Great Masurian Lakes system. The amount of Aeromonas spp. and Aeromonas hydrophila was positively correlated with temperature, ammonium concentration and water transparency.

\section{DISCUSSION}

Based on the results of CCA analysis our studies have shown that there were clear visible relations between the presence of Aeromonas and Legionella spp. and water eutrophication variables, such as phosphorus, nitrogen,
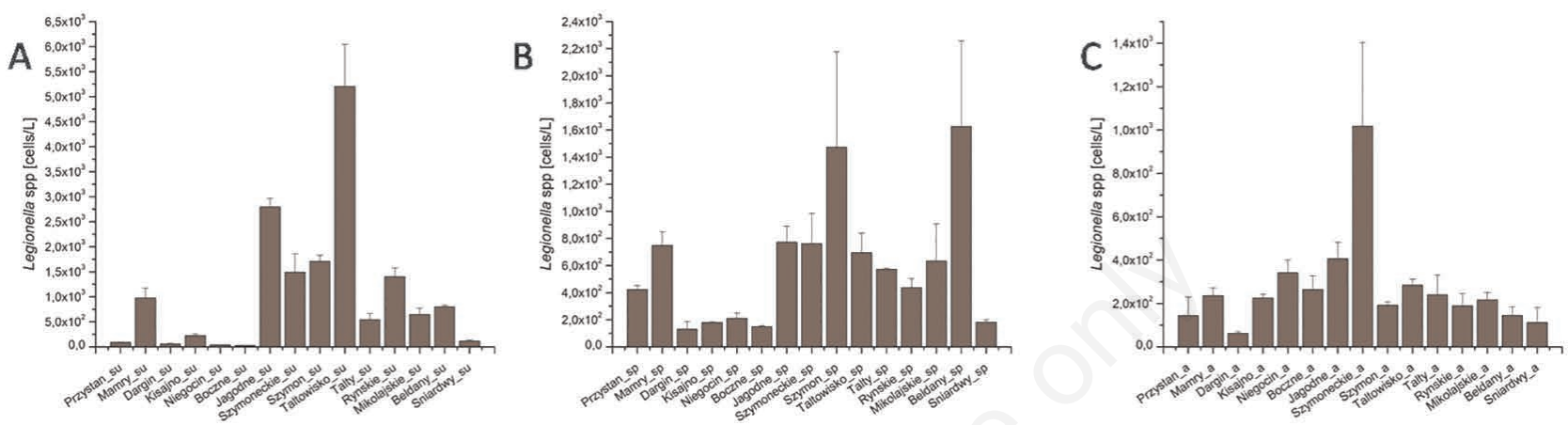

Fig. 3. Legionella spp. cells concentration in studied lakes during summer (a), spring (b) and autumn (c) seasons. Suffixes added to sampling locations (lake's names) indicate the studied seasons:_su, summer; _sp, spring; _a, autumn.
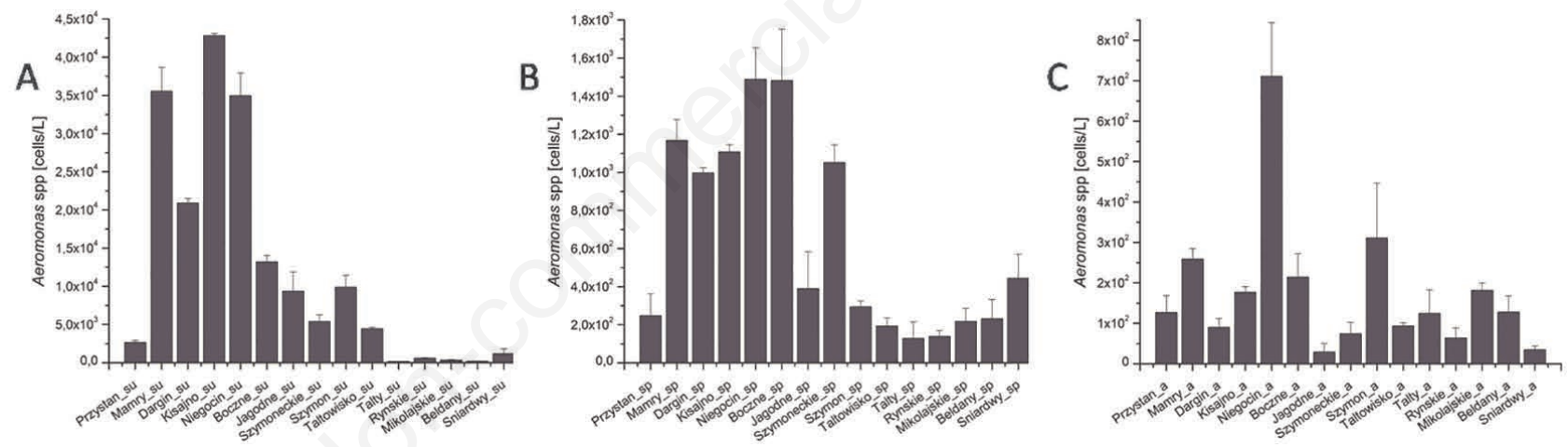

Fig. 4. Aeromonas spp. cells concentration in studied lakes during summer (a), spring (b) and autumn (c) seasons. Suffixes added to sampling locations (lake's names) indicate the studied seasons:_su, summer; _sp, spring;_a, autumn.
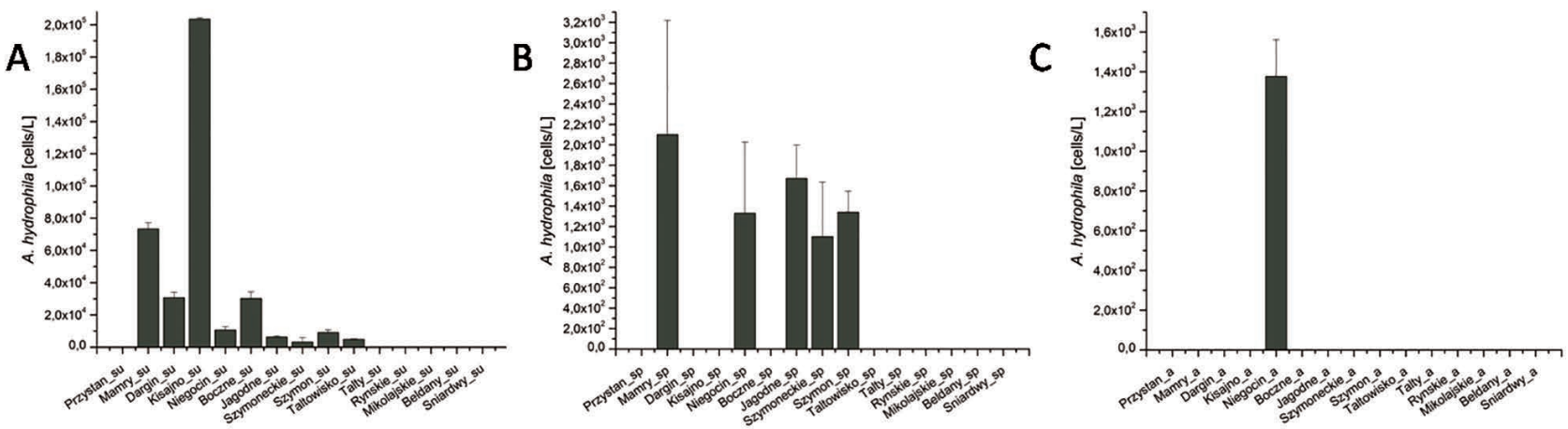

Fig. 5. Aeromonas hydrophila cells concentration in studied lakes during summer (a), spring (b) and autumn (c) seasons. Suffixes added to sampling locations (lake's names) indicate the studied seasons:_su, summer; _sp, spring; _a, autumn. 
ammonia and chlorophyll concentrations, conductivity, turbidity, and water transparency, that was presented by the results of CCA analysis. This demonstrates that further eutrophication of the studied lakes of the GML system can cause serious microbiological risks, both to animals and human health, which cannot be neglected.

About one hundred years ago, the Great Masurian Lakes were classified as oligotrophic water reservoirs (Gieysztor and Odechowska, 1958). During the 1950s eutrophication began to accelerate significantly as a consequence of human activity and speeding up of the urban development (Kauppinen, 2013). Intensification of agriculture, tourism development and expansion of towns and villages began significant changes in the surroundings of the Great Masurian Lakes system as well in the water reservoirs themselves (Siuda et al., 2020). More than half of the lakes were supplied with municipal and camping sewage (Ozimek and Kowalczewski, 1984). According to Kajak et al. (1975) during the 1970s the Mikołajskie Lake was highly eutrophicated. During the 1980s the southern lakes of the system became hyper-eutrophicated. Regarding northern lakes, with short-term exceptions, their trophic state was at the meso-eutrophy level. The main sources of nutrients in their case are tourism and agriculture (Wołos et al., 2009). In the 1990s especially in the southern part of Great Masurian Lakes system trophic state began to descend, because of modernization of sewage treatment plant that was discarding the effluent and limiting the inflow of industrial and agricultural wastewater to Niegocin Lake. Since about 2005 the oligotrophication decelerated and subsequently even reversed. Therefore, we are still dealing with the effects of accelerated eutrophication (Kauppinen, 2005).

The GML system consists of a complex system of water reservoirs with a wide variety of physicochemical characteristics. The grouping of similar sampling points in terms of their physicochemical properties simultaneously with their proximities in geographical terms was clearly visible. Sampling site located within Śniardwy Lake was an exception. It was similar to the group of northern lakes in terms of physicochemical properties and in terms of Legionella and Aeromonas spp. content profile, even though it was one of the most southern sites studied within the research area. This result may be due to the significant remoteness of the studied sites from the rest and the location within a water reservoir with different characteristics than the neighboring lakes.

The similarities between water reservoirs in term of physicochemical profile (Fig. 2), at the same time in terms of the amount of potentially pathogenic microorganisms (Fig. 6) indicate the significance of environmental factors related to eutrophication in occurrence of studied bacteria (Anza et al., 2014). In our studies we observed that in case of Śniardwy and northern lakes. Śniardwy Lake is shallow, large lake that, despite the location and strong anthropopressure is in meso-eutrophic state and its

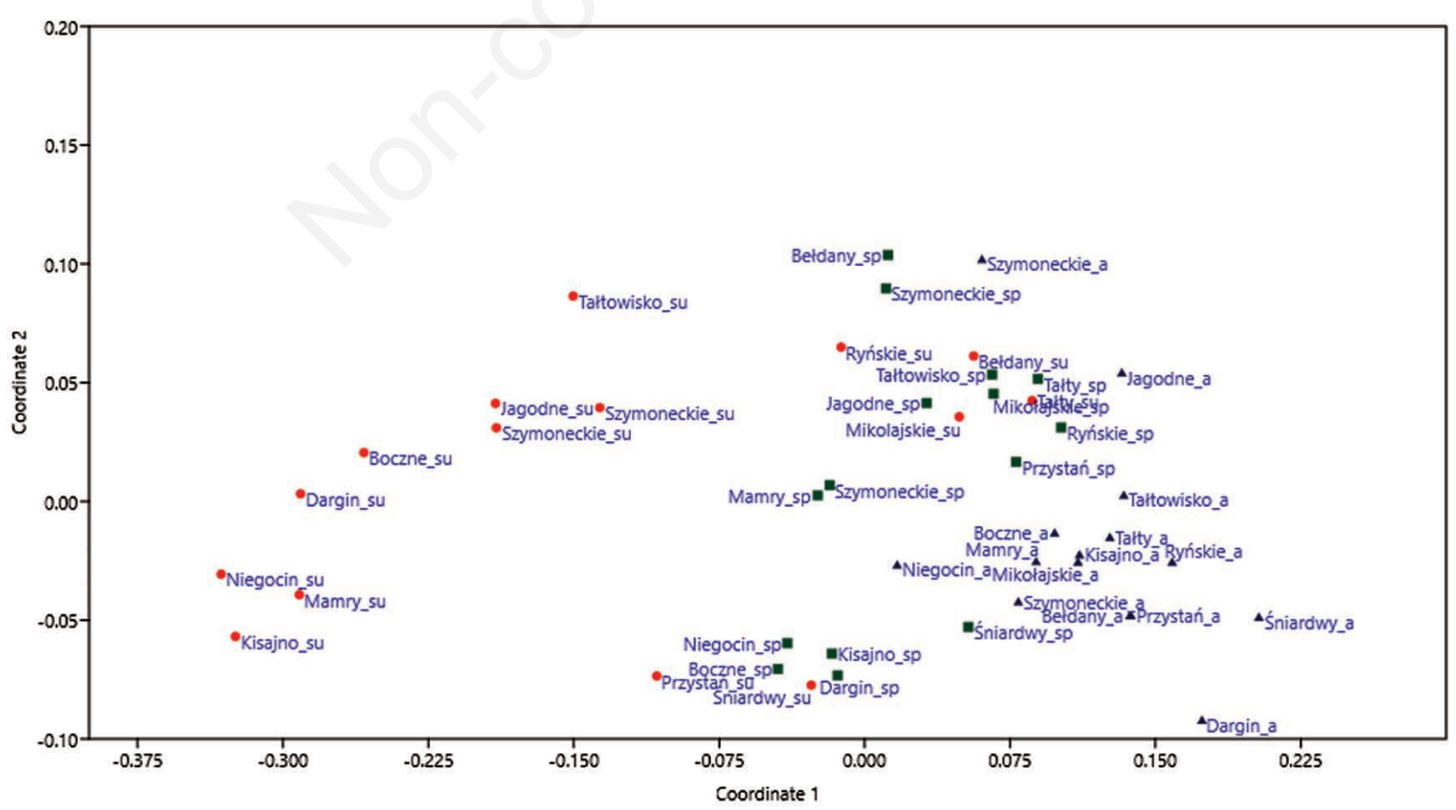

Fig. 6. The Bray-Curtis based non-metric multidimensional scaling (NMDS) of Legionella spp., Aeromonas spp. and A. hydrophila number. Stress value $=0.057$. Suffixes added to sampling locations (lake's names) and marks indicate the studied seasons: $\_$su and red dots, summer; _sp and green squares, spring;_a and dark blue triangles, autumn. 
physicochemical characteristics are similar to those characterizing northern, less eutrophicated lakes (Siuda et al., 2020), what was demonstrated in our studies by non-metric multidimensional scaling (NMDS) analysis. Additionally, NMDS analysis showed that the lakes located next to each other have a similar profile of potentially pathogenic bacteria: Legionella and Aeromonas spp. This suggests that water is a mediator in the transmission of pathogens.

The ANOSIM test showed that there are significant differences regarding the presence of pathogens in the different sampling seasons. In general, the largest amount of Legionella and Aeromonas spp. was observed in summer period, at the peak of the growing season that was also the peak of the tourist season. That corresponds with the previous study (Siuda et al., 2020), where during the peak of tourist season, the substantial amount of pollutants is generated by the yacht ports and runoffs more than usual.

The results of CCA analysis showed that the presence of potentially pathogenic Legionella and Aeromonas was associated with factors being indicators of the trophic states of the studied lakes (chlorophyll $a$ concentration, total phosphorus amount, total nitrogen amount, ammonium concentration, water transparency). Eutrophication of aquatic environments, which is manifested by increases in water productivity resulting from nutrient enrichment, is one of the most visible examples of negative human impacts to the biosphere (Smith et al., 1999). Nutrient enrichment interacts with the ecological stability of a system and determines the presence of other contaminants, including infectious disease agents (Smith and Schindler, 2009). The characterization of the trophic state of an aquatic ecosystem includes the definition of biogenic substances, mainly phosphorus, chlorophyll $a$ concentration and water transparency (Petrucio et al., 2005). The use of three variables to determine the trophic status in our studies was justified because it is not always possible to determine the trophic state of a studied lake with a single variable. For example, in the case of Mamry Lake, we observed very low chlorophyll $a$ concentrations indicating an oligotrophic conditions of a lake, while the turbidity was quite high and did not result from a large amount of phytoplankton; moreover, both the transparency and phosphorus content pointed to a mesotrophic state.

Chlorophyll $a$ concentration is an indicator of the abundance of photosynthetic organisms. In lake ecosystems, photosynthetic organisms are the base of the food chain and influence the trophic state. Nutrient content is one of the major factors that regulate photosynthesis. Hence, these parameters were considered when determining the index values of the trophic state. Previous study reported that the trophic conditions of lake water had significantly positive effects on the total

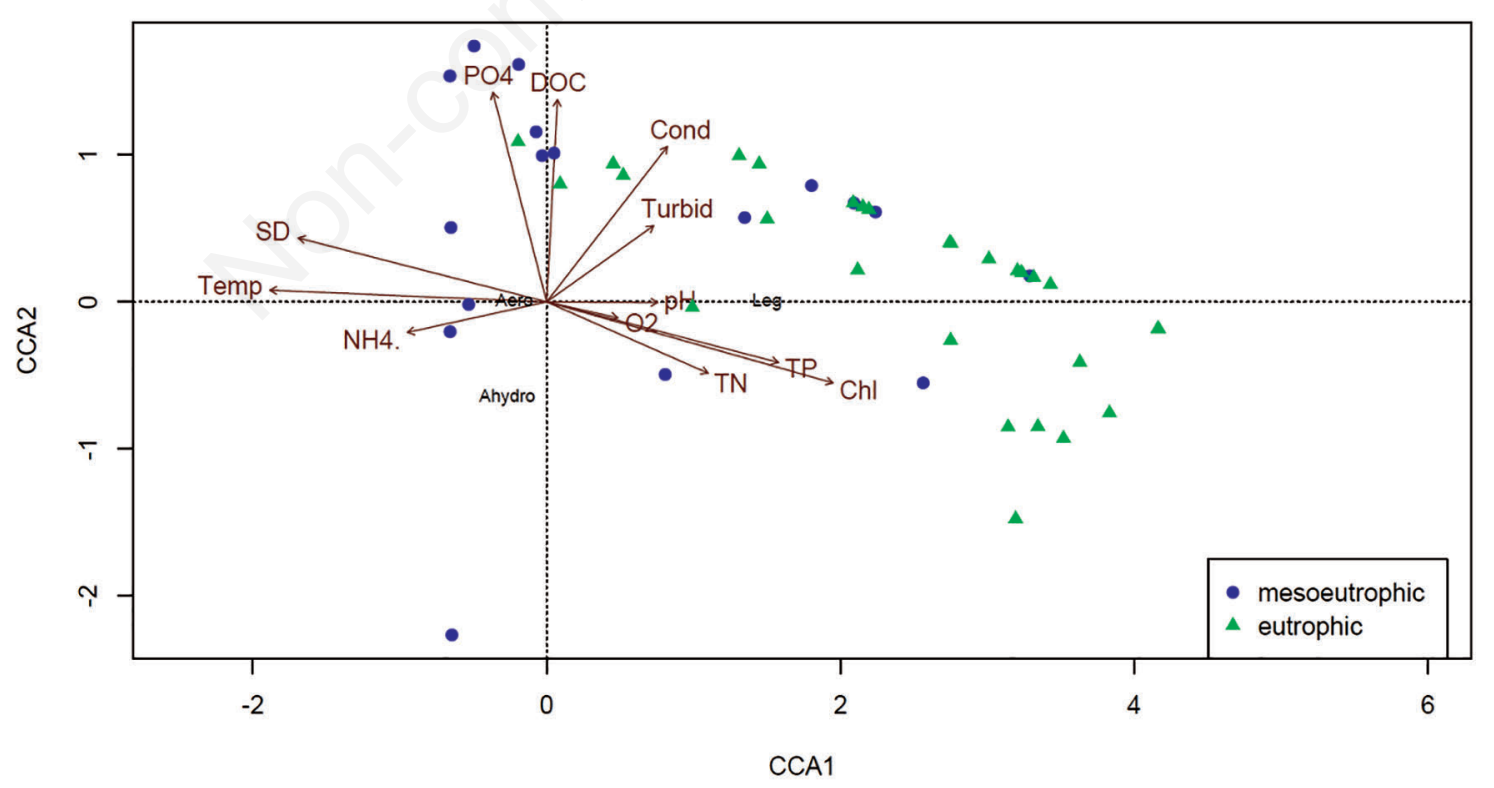

Fig. 7. Canonical correspondence analysis (CCA) results. The CCA1 explains $72 \%$ of variability, while CCA 2 explains $2 \%$. Cond, conductivity $\left(\mu \mathrm{s} \mathrm{cm}^{-2}\right)$; DOC, dissolved organic carbon $(\mathrm{mg} \mathrm{L}) ; \mathrm{PO}_{4}$, orthophosphates amount $\left(\mu \mathrm{g} \mathrm{L}{ }^{-1}\right)$; Chl, chlorophyll $a$ concentration $\left(\mu \mathrm{g} \mathrm{L}^{-1}\right)$, TP, total phosphorus amount $\left(\mu \mathrm{g} \mathrm{L}^{-1}\right)$; TN , total nitrogen amount $\left(\mu \mathrm{g} \mathrm{L}^{-1}\right)$; Turbid, turbidity (NTU); Temp, temperature $\left({ }^{\circ} \mathrm{C}\right)$; $\mathrm{O}_{2}$, oxygen concentration $\left(\mathrm{mg} \mathrm{O}_{2} \mathrm{~L}^{-1}\right)$; $\mathrm{SD}$, Secchi disc visibility $[\mathrm{m}] ; \mathrm{NH}_{4}^{+}$, ammonium concentration (mg L ${ }^{-1}$ ); Leg, Legionella spp. number (cells L ${ }^{-1}$ ); Aero, Aeromonas spp. number (cells L ${ }^{-1}$ ); A. hydro, Aeromonas hydrophila (cells L ${ }^{-1}$ ). 
numbers of bacteria, HNF (Heterotrophic Nanoflagellates) and other biotic variables of the Great Masurian Lake system (Chróst and Siuda, 2006).

What deserves attention is the effect of ammonium on the amount of Aeromonas spp. and Aeromonas hydrophila. Ammonium is a widespread pollutant in aquatic ecosystems originating directly and indirectly from human activities, which can strongly affect the structure and functioning of the aquatic foodweb and microbial structure (Leoni et al., 2018).

In aquatic environments, autochthonous microflora can use trace amounts of nutrients. In the case of allochthonous bacteria, growth deceleration is usually observed after entering nutrient-poor aquatic environments. In this adaptive phase, bacteria adjust to new environmental conditions. The more oligotrophic the environment, the longer the adaptation time because of the time needed to reorganize the enzyme systems in the microbial cells (Jones et al., 2004). Therefore, the higher the eutrophic status, the shorter the adaptation and growth restraint time (Nazari-Sharabian et al., 2018). Consequently, environments more abundant in nutrients promote the survival and growth of microflora. For this reason, the pollution of water bodies, introduced with surface runoffs, related to human recreational activity, contributes not only to the introduction of allochthonous pathogenic bacteria but also to their propagation.

Under unfavorable environmental conditions, bacterial cells are able to survive by inhibiting their growth rates and slowing down their metabolism. Different survival strategies of allochthonous bacteria in aquatic environments allow for the extension of survival time, e.g., after temperature decreases. Bacterial cells pass into the VBNC (viable but not culturable) state that is characteristic for living but non-cultivable cells, and these cells also constitute a threat to public health. Bacteria being in the VBNC state in fact are still virulent (Colwell 2000). Legionella spp. are an example of bacteria, which commonly enter a VBNC state in water environments. This state is induced often by nutrient starvation. There is a huge threat for water reservoirs safety, because increased trophic state caused by the nutrient supply can cause a sudden multiplication of these bacteria through resuscitation (Edagawa et al., 2015; Garner et al., 2018). VBNC state formation is one of reason for using a sensitive molecular biology technique, which is real-time PCR. This method is also justified due to the fact that only a small part of the bacteria community (approximately $0.1 \%$ ) inhabiting the environment is cultivable (Cho and Giovannoni, 2004; Dupont et al., 2014). Moreover, several studies show that molecular methods are an advantage over classic cultivation methods (Lleo et al., 2005; Wade, 2011; Rhoads et al., 2012).

The relation between temperature and the presence of potentially pathogenic Aeromonas bacteria also deserves attention. Similar relationships can be observed in other studies (Jin et al., 2018). This can be particularly dangerous in the context of climate change and increasing surface water temperatures (Mujere and Moyce, 2016).

Because nutrient loading, and hence eutrophication, will become more severe and widespread, eutrophication will continue to be an important factor in the etiology of human diseases. Eutrophication is, in fact, a problem that is very difficult to reverse. In freshwater, nutrients that are stored in sediments can be rapidly recycled (Johnson and Carpenter, 2008). This means that de-eutrophication is a very slow process and a strongly eutrophicated water reservoir can be a microbiological threat for a long time. The problem of dependence between trophic status and the presence of pathogenic bacteria is far-reaching and requires attention. This is particularly motivated by the fact, that previous studies have shown that Legionella and Aeromonas spp. infection is associated with the ability to thrive and persist in environment as a result of environmental selection. That is why we have referred the presence of Legionella and Aeromonas spp. to the environmental conditions.

The correlation between the studied bacteria and environmental factors related to anthropopressure causing eutrophication indicated, that there is justified urgent need of monitoring microbiological quality of natural waters and considering different species of microorganisms in lakes which may cause sanitary and health problems.

\section{CONCLUSIONS}

The study showed, that factors related to the eutrophication of surface waters are related to the presence of potentially pathogenic bacteria: Legionella and Aeromonas spp. That is particularly important in context of the ongoing eutrophication of surface water. This is the first study aimed to monitor the presence of those microorganisms over several study seasons in the waters of the Great Masurian Lakes system. Our findings suggest that further degradation of the aquatic ecosystem due to eutrophication constitutes a serious threat to human and animal health.

\section{ACKNOWLEDGMENTS}

This work was financially supported by National Science Centre, Poland, grant OPUS2015/17/B/NZ9/ 01552 awarded to R.J.C. Field studies were performed in Research Station in Mikołajki of Nencki Institute of Experimental Biology, Polish Academy of Sciences, 3 Pasteur Str., 02-093 Warsaw, Poland. We would like to thank dr. Elżbieta Terech-Majewska from Department of 
Epizootiology in the Faculty of Veterinary Medicine at University of Warmia and Mazury in Olsztyn for Aeromonas strains which we used as reference control in real-time PCR analysis.

\section{REFERENCES}

Ahmed T, Scholz M, Al-Faraj F, 2016. Water-related impacts of climate change on agriculture and subsequently on public health: a review for generalists with particular reference to Pakistan. Int. J. Environ. Res. Public Health 13:1051.

Amaro F, Wang W, Gilbert JA, Anderson OR, Shuman HA, 2015. Diverse protist grazers select for virulence-related traits in Legionella. ISME J. 9:1607-1618.

Anza I, Vidal D, Laguna C, Diáz-Sánchez S, Sánchez S, Chicote A, Florin M, Mateo R, 2014. Eutrophication and bacterial pathogens as risk factors for avian botulism outbreaks in wetlands receiving effluents from urban wastewater treatment plants. Appl. Environ. Microbiol. 80:4251-4259.

Arnone RD and Walling JP, 2007. Waterborne pathogen in Urban Watershed. J. Water Health 5:149-162.

Arrar EJ and Collins GB, 1997. Method 445.0. In vitro determination of chlorophyll a and phenophytin a in marine and freshwater algae by fluorescence. National Exposure Research Laboratory. Office of Research and Development. U.S. Environmental Protection Agency.

Barna Z, Kàdàr M, Kàlmàn E, Scheirich Szax A, Vargha M, 2015. Prevalence of Legionella in premise plumbing in Hungary. Water Res. 90:71-78.

Batra P, Mathur P, Misra MC, 2016. Aeromonas spp.: an emerging nosocomial pathogen. J. Lab. Physicians. 8:1-4.

Beaz-Hidalgo R, Alperi A, Buján N, Romalde JL, Figueras MJ, 2010. Comparison of phenotypical and genetic identification of Aeromonas strains isolated from diseased fish. Syst. Appl. Microbiol. 33:149-153.

Binder S, Levitt AM, Sacks JJ, Hughes JM, 1999. Emerging infectious diseases: public health issues for the 21 st Century. Science 284:1311-1313.

Borella P, Guerrieri E, Marchesi I, Bondi M, Messi P, 2005. Water ecology of Legionella and protozoan: environmental and public health perspectives. Biotechnol. Annu. Rev. 11:355-380.

Carlson RE, 1977. A trophic state index for lakes. Limnology and Oceanography. 22:361-369.

Cavicchioli R, Ripple W, Timmis KN, Azam F, Bakken LR, Baylis M, Behrenfeld MJ, Boetius A, Boyd PW, Classen AT, Crowther TW, Danovaro R, Foreman CM, Huisman J, Hutchins DA, Jansson JK, Karl DM, Koskella B, Mark Welch DB, Martiny JBH, Moran MA, Orphan VJ, Reay DS, Remais JV, Rich VI, Singh BK, Stein LY, Stewart FJ, Sullivan MB, van Oppen MJH, Weaver SC, Webb EA, Webster NS, 2019. Scientists' warning to humanity: microorganisms and climate change. Nat. Rev. Microbiol. 17:569-586.

Cho JC, Giovannoni SJ, 2004. Cultivation and growth characteristics of a diverse group of oligotrophic marine Gammaproteobacteria. Appl. Environ. Microbiol. 70:432-440.

Cho KH, Pachepsky YA, Oliver DM, Muirhead RW, Park Y, Quilliam RS, Shelton DR, 2016. Modeling fate and transport of fecally-derived microorganisms at the watershed scale: State of the science and future opportunities. Water Res. 100:38-56.

Chróst RJ, Siuda W, 2006. Microbial production, utilization, and enzymatic degradation of organic matter in the upper trophogenic layer in the pelagial zone of lakes along a eutrophication gradient. Limol. Oceanogr. 51:749-762.

Colwell RR, 2000. Viable but non-culturable bacteria: a survival strategy. J. Infect. Chemother. 6:121-125.

Correll DL, 1999. Phosphorus: a rate limiting nutrient in surface waters. Poult. Sci. 78:674-682.

Devos L, Boon N, Verstraete W, 2005. Legionella pneumophila in the environment: the occurrence of a fastidious bacterium in oligotrophic conditions. Rev. Environ. Sci. and Biotechnol. 4:61-74.

Dimitriadi D and Velonakis E, 2014. Detection of Legionella spp from domestic water in the prefecture of Arta, Greece. J. Pathog. 2014:407385.

Dorner SM, Anderson WB, Slawson RM, Kouwen N, Huck PM, 2006. Hydrologic modeling of pathogen fate and transport. Environ. Sci. Technol. 40:4746-4753.

Dupont S, Carre-Mlouka A, Domart-Coulon I, Vacalet J, Bourguet-Kondracki ML, 2014. Exploring cultivable Bacteria from the prokaryotic community associated with the carnivorous sponge Asbestopluma hypogea. FEMS Microbiol. Ecol. 88:160-174.

Edagawa A, Kimura A, Kawabuchi-Kurata T, Adachi S, Furuhata K, Miyamoto H, 2015. Investigation of Legionella contamination in Bath water samples by culture, amoebic co-culture and real-time quantitative PCR methods. Int. J. Environm. Res. Public Health. 12:13118-13130. Doi: 10.3390/ijerph121013118.

Garner E. McLain J, Bowers J, Engelthaler DM, Edwards MA, 2018. Microbial ecology and water chemistry impact regrowth of opportunistic pathogens in full-scale reclaimed water distribution systems. Environ. Sci. Technol. 52:90569068.

Gieysztor M, Odechowska Z, 1958. Observations on the thermal and chemical properties of Mazurian lakes in the Giżycko region. Polskie Archiwum Hydrobiologii 4:123-152.

Holmes RM, Aminot A, Kérouel R, Hooker BA, Peterson BJ, 1999. A Simple and precise metod for measuring ammonium in Marine and freshwater ecosystem. Can. J. Fish. Aquat. Sci. 56:1801-1808.

Janda JM and Abbot SL, 2010. The genus Aeromonas: taxonomy, pathogenicity and infection. Clin. Microbiol. Rev. 23:35-73.

Jin D, Kong X, Cui B, Jin S, Xie Y, Wang X, Deng Y, 2018. Bacterial communities and potential waterborne pathogens within the typical urban surface waters. Sci. Rep. 8:13368.

Johnson PTJ, Carpenter SR, 2008. Influence of eutrophication on disease in aquatic ecosystems: patterns, processes and predictions, p. 71-99. In: R. Ostfeld (ed.), Infectious disease ecology: Effects of ecosystems on disease and of disease on ecosystems. Princeton University Press.

Jones T, Gill CO, McMullen LM, 2004. The behaviour of log phase Escherichia coli at temperatures that fluctuate about the minimum for growth. Lett. Appl. Microbiol. 39:296-300.

Jung AV, Le Cann P, Roig B, Thomas O, Baurès E, Thomas MF, 2014. Microbial contamination detection in water resources: 
interest of current optical methods, trend and need in the context of climate change. Int. J. Environ. Public Health 11:4292-4310.

Kajak Z, Ławacz W, Wiśniewski RJ, Rybak IJ, and Dusoge K, 1975. Ecosystem of the Mikołajskie Lake: The fate of organic matter of the profundal zone. Polskie Archiwum Hydrobiologii 22:89-99.

Kauppinen E, 2013. Trophic state of the Great Masurian Lakes system in the past, present and future - causes, mechanisms and effects of changes. PhD Thesis, University of Warsaw. Available at: https://depotuw.ceon.pl/bitstream/handle/item/ 467/Elsi\%20Kauppinen $\% 20$ thesis.pdf? sequence $=1$.

Khan IU, Loughborough A, Edge TA. 2009.DNA-based realtime detection and quantification of aeromonads from fresh water beaches on Lake Ontario. J. Water Health. 7:312-323.

Koroleff FI, 1983. Determination of phosphorus, p. 125-139. In: K. Grasshoff, M. Ehrhardt and K. Kremling (eds.), Methods in seawater analysis. Verlag-Chemie, Weinheim.

Králová S, Staňková E, Sedláček I, 2016. Classification of Aeromonas spp. isolated from water and clinical sources and distribution of virulence genes. Folia Microbiol. 61:513-521.

Leoni B, Patelli M, Soler V, Nava V, 2018. Ammonium transformation in 14 lakes along a trophic gradient. Water $10: 265$.

Levy K, Woster AP, Goldstein RS, Carlton EJ, 2016. Untangling the impacts of climate change on waterborne diseases: A systematic review of relationships between diarrheal diseases and temperature, rainfall, flooding, and drought. Environ. Sci. Technol. 50:4905-4922.

Lizana X, López A, Benito S.Augistí G, Ríos M, Piqué N, Marqués AM, Codony F, 2017. Viability qPCR, a new tool for Legionella risk management. Int. J. Hyg. Environ. Health. 220:1318-1324.

Martino ME, Fasolato L, Montemurro F, Novelli E, Cardazzo B, 2014. Aeromonas spp.: ubiquitous or specialized bugs? Environ. Microbiol. 16:1005-1018.

Mujere N, Moyce W, 2016. Climate change impacts on surface water quality, p. 322-340. In: W. Ganpat and W-A. Isaac (eds.), Environmental sustainability and climate change. Adaptation strategies. Information Science Reference, Hershey.

Nadkarni MA, Martin FE, Jacques NA, Hunter N, 2002. Determination of bacterial load by real-time PCR using a broad-range (universal) probe and primers set. Microbiology 148:257-266.

Nazari-Sharabian M, Ahmad S, Karakouzian M, 2018. Climate change and eutrophication: a short review. Eng. Technol. Appl. Sci. Res. 8:3668-2672.
Nguyen ML, Yu VL, 1991. Legionella infection. Clin. Chest. Med. 12:257-268.

Ozimek T, Kowalczewski A, 1984. Long-term changes of the submerged macrophytes in eutrophic Lake Mikołajskie (North Poland). Aquatic Botany 19:1-11.

Pandey PK, Kass PH, Soupir ML, Biswas S, Singh VP, 2014. Contamination of water resources by pathogenic bacteria. AMB Express 4:51.

Pasqualina L, Gambuzza ME, Delia S, 2017. Legionella risk assessment in cruise chips and ferries. Ann. Agric. Environ. Med. 24:276-282.

Petrucio MM, Medeiros AO, Rosa CA, Barbosa FAR, 2005. Trophic state and microorganisms community of major subbasins of the middle Rio Doce basin, southeast Brazil. Braz. Arch. Biol. Technol. 48:625-633.

Richards AM, Von Dwingelo JE, Price CT, Kwaik YA, 2014. Cellular microbiology and molecular ecology of Legionellaamoeba interaction. Virulence 4:307-314.

Sebastião F, Lemos EG, and Pilarski F, 2018. Development of an absolute quantitative real-time PCR (qPCR) for the diagnosis of Aeromonas hydrophila infections in fish. ActaSci. Microbiol. 1:23-29.

Siuda W, Grabowska K, Kaliński T, Kiersztyn B, Chróst RJ, 2020. Trophic state, eutrophication and the threats for water quality of the Great Mazurian Lakes System, p. 231-260. In: E. Korzeniewska and M. Harnisz (eds.), Polish River Basins and Lakes - Part I. Hydrology and Hydrochemistry. Springer, Cham.

Siuda W, Kiersztyn B, 2014. Urea in lake ecosystem: the origin, concentration and distribution in relation to trophic state of the Great Masurian Lakes (Poland). Pol. J. Ecol. 63:110123.

Smith VH and Schindler DW, 2009. Eutrophication science: where do we go from here? Trends Ecol. Evol. 24:201-207.

Smith VH, Tilman GD, Nekola JC, 1999. Eutrophication: impacts of excess nutrient inputs on freshwater, marine, and terrestrial ecosystems. Environ. Pollut. 100:179-196.

Wacnik A, 2009. From foraging to farming in the Great Mazurian Lake District: palynological studies on Lake Miłkowskie sediments, northeast Poland. Veget. Hist. Archaeobot. 18:187-203.

WHO, 2016. The situation of water-related infectious diseases in the pan-European region.

Wołos A, Zdanowski B, Wierzchowska M, 2009. Long-term changes in commercial fish catches in Lake Mamry Północne (northeastern Poland) on the background of physical, chemical and biological data. Arch. Pol. Fish. 17:195-210. 